\title{
Nutritional composition and aerobic stability of wheat and corn silages stored under different environmental conditions
}

\section{Composição nutricional e estabilidade aeróbia de silagens de trigo e milho armazenadas em diferentes ambientes}

\author{
Marcos Rogério Oliveira ${ }^{1}$; Antônio Vinícius Iank Bueno²; \\ Guilherme Fernando Mattos Leão ${ }^{3 *}$; Mikael Neumann"; Clóves Cabreira Jobim ${ }^{5}$
}

\begin{abstract}
We aimed to evaluate nutritional quality, fermentation profile, aerobic stability, and dry matter losses in corn (Zea mays) and wheat (Triticum aestivum 'BRS Umbu') silages. Treatments included uninoculated and inoculated (Lactobacillus plantarum and Pediococcus acidilactici, $1.0 \times 10^{5} \mathrm{UFC} \mathrm{g}^{-1}$ ) wheat silage, corn silage from a conventional hybrid and a transgenic hybrid. Nutritional quality and fermentation profile variables were tested in a completely randomized design. Means were compared using Tukey's test at 5\% significance. An aerobic stability trial was conducted in a factorial design with two silages (wheat $\times$ inoculated wheat; conventional hybrid corn $\times$ transgenic hybrid corn) and two temperatures (ambient temperature $\times$ controlled temperature at $24^{\circ} \mathrm{C}$ ). Data were submitted to ANOVA and means were analyzed by the $\mathrm{F}$ test at $5 \%$ probability. Inoculation of wheat silage increased dry matter, organic matter, and total carbohydrates, but reduced crude protein by a dilution effect. Regarding the fermentation profile, inoculation reduced acetic acid and butyric acid content, whereas it increased propionic acid in wheat silage. Bt corn hybrid silage showed higher dry matter and lower neutral detergent fiber, whereas transgenic corn silage showed lower content of acetic acid, propionic acid, alcohol, and ammonia. Conversely, $\mathrm{B} t$ hybrid silage showed higher butyric acid. Transgenic corn silage showed higher temperature than the conventional hybrid silage during aerobic exposure. Inoculated wheat silage experienced larger deterioration and dry matter losses during the aerobic stability trial. Temperature control worsened aerobic stability in all treatments, increasing dry matter losses and heating.
\end{abstract}

Key words: Total digestible nutrients. Fermentative pattern. Dry matter losses.

\section{Resumo}

Objetivou-se avaliar a qualidade nutricional, perfil fermentativo, assim como a estabilidade aeróbia e perdas de matéria seca das silagens das silagens de milho (Zea mays) e trigo (Triticum aestivum 'BRS Umbu'). Os tratamentos foram a silagem de trigo sem inoculante, silagem de trigo com inoculante bacteriano (Lactobacillus plantarum e Pediococcus acidilactici na concentração de 1,0 $\times 10^{5}$ UFC $\mathrm{g}^{-1}$ ), silagem de milho convencional e silagem de milho transgênico. Para as variaveis relacionadas

${ }^{1}$ Prof. Dr., Instituto Federal Goiano, Campos Belos, GO, Brasil. E-mail: marcos.oliveira@ifgoiano.edu.br

${ }^{2}$ Médico Veterinário, M.e, Discente de Doutorado em Zootecnia, Universidade Estadual de Maringá, UEM, Maringá, PR, Brasil. E-mail: antonio.iank.bueno@gmail.com

3 Médico Veterinário, M.e, Discente Doutorado em Zootecnia, Universidade Federal do Paraná, UFPR, PR, Brasil. E-mail: gfleao@ hotmail.com

${ }^{4}$ Prof. Dr., Universidade Estadual do Centro Oeste, UNICENTRO, Guarapuava, PR, Brasil. E-mail: neumann.mikael@hotmail. com

5 Prof. Dr., UEM, Maringá, PR, Brasil. E-mail: ccjobim@uem.br

* Author for correspondence 
a qualidade nutricional, assim como perfil fermentativo o delineamento utilizado foi o inteiramente casualizado e as médias foram analisadas pelo teste Tukey ao nível de 5\%. Já com relação a estabilidade aeróbia, o delineamento estatístico foi o inteiramente casualizado, em esquema fatorial, sendo 2 silagens (silagem de trigo $\times$ silagem de trigo com inoculante; silagem de milho convencional $\times$ silagem de milho transgênico) e 2 ambientes em avaliação (temperatura ambiente $\times$ temperatura controlada à 24 ${ }^{\circ} \mathrm{C}$ ). Os dados coletados foram submetidos à análise de variância e as médias foram analisadas pelo teste $\mathrm{F}$ ao nível de 5\%. A inoculação da silagem de trigo promoveu maior conservação de matéria seca, matéria orgânica e carboidratos totais, levando a redução da concentração de proteína bruta, por efeito de diluição, quando comparada a silagem controle. A silagem de trigo inoculada apresentou os teores reduzidos de ácido acético e butírico, porém teor mais elevado de ácido propiônico. Houve maior concentração de matéria seca e menor teor de fibra em detergente neutro para a silagem de milho Bt. A silagem de milho transgênico apresentou menores teores de ácido acético, ácido propiônico, álcool e amônia e teor de ácido butírico mais elevado. A inoculação da silagem de trigo aumentou a deterioração da massa ensilada após exposição ao ar, o que elevou as perdas de matéria seca. Para as silagens de milho, a máxima temperatura observada foi registrada na silagem de milho transgênico. $O$ controle ambiental influenciou negativamente aumentando as perdas de matéria seca e reduzindo a estabilidade de ambas as silagens.

Palavras-chave: Nutrientes digestíveis totais. Perfil fermentativo. Perdas de matéria seca.

\section{Introduction}

Ensiling aims to preserve the nutritional quality which characterizes a fodder at harvest. Accordingly, ensiled material must be kept in an anaerobic environment in order to create appropriate conditions for the development of lactic acid bacteria (LAB), which will convert soluble carbohydrates into organic acids. These acids have the ability to reduce the $\mathrm{pH}$, thereby halting enzymatic activities and limiting the growth of deleterious microorganisms; thus, leading to the preservation of the forage for long periods (JOBIM; NUSSIO, 2013).

Another important issue relates to the type of forage for ensiling, which may influence the fermentation profile experienced by silage. Whole crop corn(Zea mays) is the standard silage plant, since it combines high productivity per hectare with high nutritional quality. Additionally, its characteristics promote ideal conditions for fermentation by LAB, such as dry matter (DM) content between $30 \%$ and $35 \%$ at the time of harvest, a low buffer capacity and a high soluble carbohydrate content (JOBIM; NUSSIO, 2013).

On the other hand, in order to optimize crop performance, particularly to increase plant health, corn hybrids containing the Bt gene have been widely used. However, some differences in chemical composition and fermentation can be observed in comparison with conventional hybrids (AULRICH et al., 2001; SAXENA; STOTZKY, 2001; BALIEIRO et al., 2011; KAMOTA et al., 2011).

Another cereal that is gaining acceptance for silage production is wheat (Triticum aestivum), as an alternative fodder during off-season periods. Wheat is an interesting option due to its good productivity and nutritional quality (MEINERZ et al. 2011). However, due to the high buffer capacity and a lower concentration of soluble carbohydrates presented by wheat, undesirable fermentations may occur in this type of material (MCDONALD et al., 1991). Therefore, the use of inoculants containing homolactic bacteria may be useful, as they transform the carbohydrates consumed into lactic acid with a more efficient use of energy (PAHLOW et al., 2003).

Nevertheless, during exposure to oxygens, spoilage microorganisms development, especially yeasts, implies the consumption of soluble substrates (such as carbohydrates, proteins, and fermentation products), which could potentially be used by cattle (WILKINSON; DAVIES, 2013). Thus, it is essential to evaluate this parameter in order to develop measures to control deterioration 
during the period of unavailability of the silo. It is important to emphasize that an ambient temperature above $10^{\circ} \mathrm{C}$ may have an influence on the evaluation of the aerobic stability of silages (ASHBELL et al., 2002). Therefore, the evaluation of the aerobic stability in more than one environment is important for decision-making in the attempt to control forage deterioration.

Therefore, the objective of this study was to evaluate the nutritional quality, fermentation profile and aerobic stability of conventional and transgenic corn silages, as well as wheat silage, treated with homolactic inoculant under different environments.

\section{Material and Methods}

Experiments were carried out in the animal production sector of the State University of the Center-West (UNICENTRO) and in the ruminant nutrition sector of the State University of Maringá, in 2012. Experimental treatments included wheat silage (WS), wheat silage with bacterial inoculant (WSI), conventional corn silage (CCS), and transgenic corn silage (TCS).

Conventional and transgenic corn crops were planted in the second half of October 2010, under a No-tillage system, in succession with a forage mixture of black oats (Avena strigosa) and ryegrass (Lolium multiflorum), using $80 \mathrm{~cm}$ row spacing and seeding depth of $4 \mathrm{~cm}$. Five seeds were planted per linear meter. The conventional hybrid AG 8088 and its isogenic counterpart carrying the $B t$ gene were used in an area of 1 hectare for each hybrid.

Basic fertilization of the corn crop consisted in application of $350 \mathrm{~kg} \mathrm{ha}^{-1}$ of NPK fertilizer 08-30$20\left(\mathrm{~N}-\mathrm{P}_{2} \mathrm{O}_{5}-\mathrm{K}_{2} \mathrm{O}\right)$. Coverage fertilization consisted in $120 \mathrm{~kg} \mathrm{ha}^{-1}$ of $\mathrm{N}$ in the form of urea (46-00-00) applied when the plants had four expanded leaves, as recommended for a corn crop for grain production by the Soil Fertility Commission of Santa Catarina and Rio Grande do Sul (CQFS-RS/SC, 2004). Corn plants were harvested at physiological maturity during formation of chalky to hard corn grain, 121 days after emergence.

In the first half of June 2011, wheat was planted in succession, with a row spacing of $0.17 \mathrm{~cm}$, at a depth of $2 \mathrm{~cm}$ and at a seed density of 220 seeds $/ \mathrm{m}^{2}$. The experimental material was wheat 'BRS Umbu' of a non-ridge, double-purpose genotype, in an area of 3 ha.

For base fertilization, $300 \mathrm{~kg} \mathrm{ha}^{-1}$ of NPK fertilizer 08-30-20 (N- $\left.\mathrm{P}_{2} \mathrm{O}_{5}-\mathrm{K}_{2} \mathrm{O}\right)$ were applied according to recommendations of the Soil Fertility Commission of Santa Catarina and Rio Grande do Sul (CQFS-RS/SC, 2004). Coverage fertilization consisted in a single dose of $118 \mathrm{~kg} \mathrm{ha}^{-1}$ of $\mathrm{N}$ in the form of urea (46-00-00), applied at tillering stage, 30 days after emergence. Wheat plants were harvested at physiological maturity, at the chalky corn ear stage, 144 days after emergence. Bacterial inoculant used for the WSI treatment was composed of Lactobacillus plantarum and Pediococcus acidilactici $\left(1.0 \times 10^{5} \mathrm{CFU} \mathrm{g}^{-1}\right)$.

Corn and wheat crops were monitored according to agronomic technical reports. Thus, 4 silos were filled, one for each treatment. The silos used were trench type, $3.5 \mathrm{~m} \mathrm{x} 11 \mathrm{~m}$ and $1.0 \mathrm{~m}$ in height; completely sealed and protected with three layers of polyethylene lining $(200 \mu)$. Opening of the storage silos was in the first half of 2012.

Samples of wheat and corn silages were collected directly from the storage silo panel for seven consecutive weeks in feed use; they were weighed immediately and then pre-dried in a forced air oven at $55^{\circ} \mathrm{C}$ for 72 hours for determination of partially dry matter.

Dry matter in the pre-dried samples (DM), mineral matter $(\mathrm{MM})$, crude protein $(\mathrm{CP})$ and crude fat $(\mathrm{CF})$ were estimated at $105^{\circ} \mathrm{C}$ according to the techniques described in Cunniff (1995). Concentration of neutral detergent fiber (NDF) with thermostable $\gamma$-amylase, acid detergent fiber (ADF), and lignin were obtained according to the method of Van Soest et al. (1991). 
Total carbohydrates (TC), non-fibrous carbohydrates (NFC) and total digestible nutrients (TDN) were calculated according to the equations of Sniffen et al. (1992). The in vitro digestibility of DM (IVDMD) and the digestibility of NDF (DNDF) were determined after Holden (1999), and Hall and Mertens (2008), respectively.

Determination of lactic acid, acetic acid, propionic and butyric acids and alcohol, were performed by gas chromatography according to Erwin et al. (1961).

Assessment of aerobic stability was done separately on the four treatments under evaluation. Silage samples $(3.5 \mathrm{~kg})$ were deposited in buckets (10 L capacity) without compaction and placed in two different environments; one without temperature control (environment 1), and the other at a constant temperature of $24^{\circ} \mathrm{C}$ (environment 2), where they remained for seven consecutive days, for a total of 168 hours.

Silage temperature was measured twice a day, at 8:00 and again at 16:00 h, using a long stem Gulterm 1001 digital thermometer inserted in the center of the silage mass. After temperature measurement, these buckets were weighed for further DM loss calculation. The $\mathrm{pH}$ values were determined daily at $17 \mathrm{~h}$ according to Silva and Queiroz (2002), on a second set of containers, as well as $25 \mathrm{~g}$ of sample were removed for calculation of DM, as described by Jobim et al. (2007), in order to assess DM loss.

The variables analyzed in the aerobic stability test included: aerobic stability (h), maximum temperature recorded $\left({ }^{\circ} \mathrm{C}\right)$; sum of observed temperatures $\left({ }^{\circ} \mathrm{C}\right)$; mean of observed temperatures $\left({ }^{\circ} \mathrm{C}\right)$, maximum observed $\mathrm{pH}$; mean $\mathrm{pH}$, time to reach maximum $\mathrm{pH}$ and dry matter loss.

Variables related to chemical composition and fermentation profile were analyzed in a completely randomized design, according to the following model: $\mathrm{Y}_{\mathrm{ij}}=\mu+\mathrm{T}_{\mathrm{i}}+\mathrm{e}_{\mathrm{ij}}$. Where: $\mu=$ overall average; $\mathrm{T}_{\mathrm{i}}=$ effect of silage ( $\mathrm{i}=1$ to 4$)$; $\mathrm{e}_{\mathrm{ij}}=$ error associated with observation $\mathrm{Y}_{\mathrm{ij}}$. Data for chemical composition and fermentation profile were submitted to ANOVA by the SAS Program (2012), and means were compared by Tukey's test at a probability level of $5 \%$.

Aerobic stability was tested in a completely randomized design with nine replicates, in a factorial scheme with 2 silages (wheat silage $\times$ wheat silage with inoculant, conventional corn silage $\times$ transgenic corn silage) and 2 environments under evaluation (ambient temperature $\times$ controlled temperature at $24^{\circ} \mathrm{C}$ ), according to the following model: $\mathrm{Y}_{\mathrm{ijk}}=\mu$ $+\mathrm{T}_{\mathrm{i}}+\mathrm{A}_{\mathrm{j}}+\mathrm{SA}_{\mathrm{ij}}+\mathrm{e}_{\mathrm{ijk}}$. Where: $\mu=$ overall mean; $\mathrm{T}_{\mathrm{i}}=$ effect of silage ( $\mathrm{i}=1$ to 2$) ; \mathrm{A}_{\mathrm{j}}=$ effect of the environment ( $\mathrm{j}=1$ to 2 ); $\mathrm{TA}_{\mathrm{ij}}=$ interaction between silage and environment; $\mathrm{e}_{\mathrm{ijk}}=$ error associated with observation $\mathrm{Y}_{\mathrm{ijk}}$. Data collected for each variable were submitted to ANOVA using the PROC GLM option of the SAS Program (2012), while means were analyzed by the F-test at 5\% significance.

\section{Results and Discussion}

As expected, corn silage yielded better results in nutritional composition, compared to wheat silage (Table 1). The intrinsic characteristics of each crop, such as physiology, morphological and chemical composition before ensiling and productivity, all of which underlie the difference in fermentation dynamics, were undoubtedly the reason for the difference in final nutritional composition of silage in each case.

Corn silage, in comparison to wheat silage, presented higher organic matter and starch content, as well as lower NDF (NDF being more digestible) and ADF values. These results led to an increase of the estimated NFC and TDN concentrations in corn silage. Due to the better nutritional composition, corn silage had higher digestibility. However, corn silage showed lower CP concentration than wheat silage; probably because wheat is a temperate $\mathrm{C} 3$ grass; thus, it has a higher proportion of the Rubisco enzyme, which increases the amount of nitrogen in the plant leaves in comparison to $\mathrm{C} 4$ grasses (TAIZ et al., 2006). 
Table 1. Chemical composition of silages of conventional or transgenic corn and wheat silages with and without inoculant.

\begin{tabular}{|c|c|c|c|c|c|}
\hline \multirow{2}{*}{ Variable } & \multicolumn{4}{|c|}{ Silage } & \multirow{2}{*}{$\mathrm{SEM}^{1}$} \\
\hline & $\mathrm{WS}^{\mathrm{a}}$ & $\mathrm{WSI}^{\mathrm{b}}$ & $\mathrm{CCS}^{\mathrm{c}}$ & $\mathrm{TCS}^{\mathrm{d}}$ & \\
\hline \multicolumn{6}{|c|}{$\mathrm{g} / \mathrm{kg}$ of $\mathrm{NM}^{\mathrm{f}}$} \\
\hline Dry matter & $400.9^{b}$ & $408.8^{\mathrm{a}}$ & $394.5^{\mathrm{b}}$ & $402.2^{\mathrm{a}}$ & 0.780 \\
\hline \multicolumn{6}{|c|}{$\mathrm{g} / \mathrm{kg}$ of DM } \\
\hline Organic matter & $961.4^{\mathrm{c}}$ & $965.5^{\mathrm{b}}$ & $970.4^{\mathrm{a}}$ & $971.8^{\mathrm{a}}$ & 0.12 \\
\hline Neutral detergent fiber & $524.8^{\mathrm{a}}$ & $533.0^{\mathrm{a}}$ & $478.3^{\mathrm{a}}$ & $457.3^{\mathrm{b}}$ & 9.67 \\
\hline Acid Detergent Fiber & $328.2^{\mathrm{a}}$ & $322.6^{\mathrm{a}}$ & $274.8^{\mathrm{b}}$ & $263.9^{b}$ & 3.26 \\
\hline Crude protein & $98.4^{\mathrm{a}}$ & $86.9^{\mathrm{b}}$ & $58.7^{\mathrm{c}}$ & $60.2^{\mathrm{c}}$ & 0.20 \\
\hline In vitro digestibility of $\mathrm{DM}$ & $637.7^{\mathrm{b}}$ & $633.3^{\mathrm{b}}$ & $674.9^{\mathrm{a}}$ & $681.0^{\mathrm{a}}$ & 3.40 \\
\hline Digestibility of NDF & $356.0^{\mathrm{b}}$ & $371.9^{b}$ & $418.8^{\mathrm{a}}$ & $405.8^{\mathrm{a}}$ & 21.37 \\
\hline Total carbohydrates & $838.4^{\mathrm{c}}$ & $858.8^{\mathrm{b}}$ & $892.8^{\mathrm{a}}$ & $890.2^{\mathrm{a}}$ & 0.39 \\
\hline Non-fibrous carbohydrates & $313.6^{\mathrm{b}}$ & $325.7^{\mathrm{b}}$ & $413.4^{\mathrm{a}}$ & $432.9^{a}$ & 0.40 \\
\hline Total digestible nutrients & $620.8^{\mathrm{b}}$ & $617.0^{\mathrm{b}}$ & $696.7^{\mathrm{a}}$ & $702.5^{\mathrm{a}}$ & 11.23 \\
\hline Starch & $180.3^{\mathrm{b}}$ & $192.0^{\mathrm{b}}$ & $279.7^{\mathrm{a}}$ & $309.5^{\mathrm{a}}$ & 5.49 \\
\hline
\end{tabular}

Means within the same row followed by different letter differ from each other $(\mathrm{P}<0.05)$ by the Tukey test.

${ }^{\mathrm{a}} \mathrm{WS}$ : wheat silage; ${ }^{\mathrm{b} W S I}$ : wheat silage inoculant; ${ }^{\mathrm{c} C C S}$ : conventional corn silage; ${ }^{\mathrm{d}} \mathrm{TCS}$ : transgenic corn silage; ${ }^{\mathrm{f}} \mathrm{NM}$ : natural matter. ${ }^{1} \mathrm{SEM}$ : standard error of the mean.

Transgenic corn silage had a higher DM content, in detriment of NDF, when compared to CCS. However, according to some reports, the transgene can negatively alter fiber quality, as there may be a greater deposition of lignified tissue by the plant, which provides higher resistance to diseases, while at the same time, it would result in increased NDF content compared to non-transgenic plants (SAXENA; STOTZKY, 2001; POERSCHMANN et al., 2005; KAMOTA et al., 2011). However, this was not observed in the present study.

Reduced levels of DM, OM and total carbohydrates were observed for WS. In this way, the consumption of soluble substrate led to an increasing of CP level in WS, by a dilution effect. The type of fermentation occurred in each silage (Table 2) played a key role, as higher concentration of acetic and butyric acids have been observed in WS. Heterolactic fermentation consumes a greater amount of soluble carbohydrates compared to homolactic fermentation, since more oxidized compounds and $\mathrm{CO}_{2}$ are formed, which are lost to the gas phase (AXELSSON, 2004). The presence of butyric acid is related to metabolism of energyrich compounds (such as pyruvate and lactic acid) by microorganisms of the genus Clostridium, with production of $\mathrm{CO}_{2}$, heat and increase in energy losses. These results indicate that inoculation of wheat silage provided better preservation of the material.

Both wheat silages displayed higher levels of ammonia compared to corn silage, which is related to the higher concentration of $\mathrm{CP}$ and buffer capacity of the former, which favors proteolysis during storage.

In our experiments, corn silage displayed lower mean lactic acid levels than those described by Kung and Shaver (2001) for this type of silage (from $6 \%$ to $10 \%$ of DM). Furthermore, TCS had the lowest content of lactic acid $(0.797 \%)$. TCS also displayed lower levels of acetic acid, propionic acid, alcohol, and $\mathrm{NH}_{3} / \mathrm{NT}$. However, the concentration of butyric acid was higher for TCS, compared to CCS; thus, denoting lower activity of heterolactic microorganisms. This behavior contrasts that described by Balieiro et al. (2011), who reported a higher concentration of propionic and acetic acids in $\mathrm{B} t$ corn silage, with no difference in relation to butyric acid. 
Table 2. Fermentation products of conventional and transgenic corn silages and wheat silages with no bacterial inoculant.

\begin{tabular}{|c|c|c|c|c|c|}
\hline \multirow{2}{*}{ Variable } & \multicolumn{4}{|c|}{ Silage } & \multirow[t]{2}{*}{ SEM } \\
\hline & $\mathrm{WS}^{\mathrm{a}}$ & $\mathrm{WSI}^{\mathrm{b}}$ & $\mathrm{CCS}^{\mathrm{c}}$ & TCS & \\
\hline & \multicolumn{5}{|c|}{ Fermentation products, \% DM } \\
\hline Lactic Acid & $1.767^{\mathrm{a}}$ & $1.867^{\mathrm{a}}$ & $2.148^{\mathrm{a}}$ & $0.797^{\mathrm{b}}$ & 0.109 \\
\hline Acetic Acid & $1.288^{\mathrm{b}}$ & $1.145^{\mathrm{c}}$ & $1.747^{\mathrm{a}}$ & $0.381^{\mathrm{d}}$ & 0.094 \\
\hline Propionic acid & $0.261^{\mathrm{bc}}$ & $0.580^{\mathrm{a}}$ & $0.533^{\mathrm{b}}$ & $0.205^{\mathrm{c}}$ & 0.010 \\
\hline Butyric Acid & $0.533^{\mathrm{a}}$ & $0.205^{\mathrm{b}}$ & $0.261^{\mathrm{b}}$ & $0.580^{\mathrm{a}}$ & 0.013 \\
\hline Alcohol & $0.777^{\mathrm{a}}$ & $0.808^{\mathrm{a}}$ & $0.680^{\mathrm{a}}$ & $0.339^{\mathrm{b}}$ & 0.014 \\
\hline $\mathrm{NH}_{3} / \mathrm{NT}$ & $10.280^{\mathrm{a}}$ & $9.880^{\mathrm{a}}$ & $3.61^{\mathrm{b}}$ & $2.27^{\mathrm{c}}$ & 0.88 \\
\hline
\end{tabular}

Means within the same row followed by different letter differ from each other $(\mathrm{P}<0.05)$ by the Tukey test.

${ }^{a}$ WS: wheat silage; ${ }^{b} \mathrm{WSI}$ : wheat silage inoculant; ${ }^{\mathrm{c}} \mathrm{CCS}$ : conventional corn silage; ${ }^{\mathrm{d}} \mathrm{TCS}$ : transgenic corn silage.

${ }^{1}$ SEM: standard error of the mean.

Inoculated wheat silage had a lower aerobic stability than WS, as shown by the significant difference $(\mathrm{P}<0.05)$ observed for stability, maximum temperature, sum, and mean temperature (Table 3). WSI silage presented lower acetic acid and butyric acid, accelerating deterioration, which was also demonstrated by Li et al. (2015). Acetic acid has the capacity to inhibit yeast and fungi development, which are responsible for starting the process of aerobic deterioration (DANNER et al., 2003). Although undesirable, butyric acid has the same effect. In addition, the higher amount of substrate in WSI silage due to the higher OM content in this fodder-likely increased microbiological growth, which in turn caused lower stability and high DM loss, compared to the uninoculated silage.

Table 3. Aerobic stability of wheat silage with and without bacterial inoculant.

\begin{tabular}{cccccc}
\hline \multirow{2}{*}{ Variables } & \multicolumn{2}{c}{ Silage } & \multicolumn{2}{c}{ Environment $^{2}$} & \multirow{2}{*}{ SEM $^{3}$} \\
\cline { 2 - 5 } & WS & WSI & N & C & 50.30 \\
Stability (h) & $141.33^{\mathrm{a}}$ & $94.44^{\mathrm{b}}$ & $153.33^{\mathrm{a}}$ & $84.44^{\mathrm{b}}$ & 5.11 \\
Max. Temp $\left({ }^{\circ} \mathrm{C}\right)$ & $21.63^{\mathrm{b}}$ & $26.62^{\mathrm{a}}$ & 22.74 & 25.51 & 43.13 \\
Sum Temp $\left({ }^{\circ} \mathrm{C}\right)$ & $288.17^{\mathrm{b}}$ & $331.85^{\mathrm{a}}$ & $285.75^{\mathrm{b}}$ & $334.27^{\mathrm{a}}$ & 2.87 \\
Mean temp $\left({ }^{\circ} \mathrm{C}\right)$ & $19.21^{\mathrm{b}}$ & $22.12^{\mathrm{a}}$ & $19.05^{\mathrm{b}}$ & $22.28^{\mathrm{a}}$ & 0.88 \\
pH max. & 4.43 & 4.88 & 4.48 & 4.83 & 0.65 \\
Mean pH & $4.17^{\mathrm{b}}$ & $4.74^{\mathrm{a}}$ & 4.52 & 4.39 & 22.49 \\
Max. pH (h) & 124 & 128 & $114.67^{\mathrm{b}}$ & $137.33^{\mathrm{a}}$ & 3.31 \\
Losses (DM) & $6.56^{\mathrm{b}}$ & $9.43^{\mathrm{a}}$ & $6.53^{\mathrm{b}}$ & $9.45^{\mathrm{a}}$ & \\
\hline
\end{tabular}

Means within the same rows followed by different letter differ from each other $(\mathrm{P}<0.05)$ by the Tukey test.

${ }^{1} \mathrm{WS}$ : wheat silage and WSI: wheat silage with inoculant.

${ }^{2} \mathrm{~N}$ : ambient temperature; C: temperature kept at $24^{\circ} \mathrm{C}$.

${ }^{3} \mathrm{SEM}$ : standard error or the mean.

When ambient temperature was maintained at $24^{\circ} \mathrm{C}$, the loss of OMwas higher. This is likelybecause this temperature is near the optimum temperature for the development of lactate-consuming organisms, as reported by Ashbell et al. (2002). These authors observed a rapid breakdown of the aerobic stability of corn and wheat silages at $30^{\circ} \mathrm{C}$, compared to higher $\left(40^{\circ} \mathrm{C}\right)$ or lower temperatures $\left(10^{\circ} \mathrm{C}\right)$. On the other hand, temperature fluctuation outside the controlled environment may retard microbiological development (RATKOWSKY et al., 1982), as there is an exchange of heat between the mass of silage 
and the environment, thus, raising the aerobic stability of silages.

The comparison between CCS and TCS silages did not reveal any significant differences regarding the stability (Table 4). The maximum temperature in hours was higher for TCS, which could be associated with the lower concentration of acetic acid in this silage.

Table 4. Aerobic stability of conventional and transgenic corn silages.

\begin{tabular}{cccccc}
\hline \multirow{2}{*}{ Variables } & \multicolumn{2}{c}{ Silage $^{1}$} & \multicolumn{2}{c}{ Environment $^{2}$} & \multirow{2}{*}{ SEM $^{3}$} \\
\cline { 2 - 5 } & $\mathrm{CCS}$ & $\mathrm{TCS}$ & $\mathrm{N}$ & $\mathrm{C}$ & 16.76 \\
Stability $(\mathrm{h})$ & 23.05 & 33.33 & $23.33 \mathrm{~b}$ & $33.05^{\mathrm{a}}$ & 5.28 \\
Max. Temp $\left({ }^{\circ} \mathrm{C}\right)$ & $29.71^{\mathrm{b}}$ & $32.29^{\mathrm{a}}$ & $27.01^{\mathrm{b}}$ & $35.00^{\mathrm{a}}$ & 36.43 \\
Sum Temp $\left({ }^{\circ} \mathrm{C}\right)$ & 337.40 & 348.17 & $309.86^{\mathrm{b}}$ & $375.72^{\mathrm{a}}$ & 2.43 \\
Mean temp $\left({ }^{\circ} \mathrm{C}\right)$ & 22.49 & 23.21 & $20.66^{\mathrm{b}}$ & $25.05^{\mathrm{a}}$ & 0.65 \\
pH max. & 7.22 & 7.23 & 7.26 & 7.18 & 0.55 \\
Mean pH & 5.73 & 5.89 & $5.63^{\mathrm{b}}$ & $5.97^{\mathrm{a}}$ & 19.72 \\
Max. pH (h) & 138.66 & 158.66 & 142.66 & 154.67 & 3.37 \\
Losses $(\mathrm{DM})$ & 15.63 & 15.52 & $12.60^{\mathrm{b}}$ & $18.56^{\mathrm{a}}$ & \\
\hline
\end{tabular}

Means within the same row followed by different letter differ from each other $(\mathrm{P}<0.05)$ by the Tukey test.

${ }^{1}$ CCS: Conventional corn silage and TCS: Transgenic corn silage.

${ }^{2} \mathrm{~N}$ : ambient temperature; C: temperature kept at $24^{\circ} \mathrm{C}$.

${ }^{3}$ SEM: Standard error of the mean.

With respect to different environments, the results were similar to those observed for wheat silages; i.e., the stability of silages that remained in the controlled environment was negatively affected, which eventually caused greater DM losses.

\section{Conclusion}

The use of inoculant on wheat protected organic matter and soluble carbohydrates from deterioration. However, there was a reduction in the aerobic stability of wheat silages compared to conventional corn silage. The transgene did not interfere with the quality of corn silage, although it did affect the fermentation process in it. Environmental control interfered negatively with aerobic stability of wheat and corn silages and increased the losses of dry matter in both cases.

\section{References}

ASHBELL, G.; WEINBERG, Z. G.; HEN, Y.; FILYA, I. The effects of temperature on the aerobic stability of wheat and corn silages. Journal of Industrial Microbiology and Biotechnology, Fairvax, v. 28, n. 5, p. 261-263, 2002.

AULRICH, K.,: BÖHME, H.; DAENICKE, R.: HALLE, I.; FLACHOWSKY, G. Genetically modified feeds in animal nutrition 1st communication: Bacillus thuringiensis $(B t)$ corn in poultry, pig and ruminant nutrition. Archives of Animal Nutrition, Berlin, v. 54, n. 3, p. 183-195, 2001.

AXELSSON, L. Lactic acid bacteria: classification and physiology. Food Science and Technology, New York, v. 139, n. 1, p. 1-66, 2004.

COMISSÃO DE QUÍMICA E FERTILIDADE DO SOLO - CQFSRS/SC. Manual de adubação e calagem para os Estados do Rio Grande do Sul e de Santa Catarina. 10. ed. Porto Alegre: SBCS - Núcleo Regional Sul/UFRGS. 2004. 400p.

CUNNIFF, P. (Ed.). Official methods of analysis of AOAC International. $16^{\text {th }}$ ed. Arlington: AOAC International, 1995. $2000 \mathrm{p}$. 
DANNER, H.; HOLZER, M.; MAYRHUBER, E.; BRAUN, R. Acetic acid increases stability of silage under aerobic conditions. Applied and Environmental Microbiology, Washington, v. 69, n. 1, p. 562-567, 2003.

ERWIN, E. S.; MARCO, G. J.; EMERY, E. M. Volatile fatty acid analyses of blood and rumen fluid by gas chromatography. Journal of Dairy Science, Madison, v. 44, n. 9, p. 1768-1771, 1961.

HALL, M. B.; MERTENS, D. In vitro fermentation vessel type and method alter fiber digestibility estimates. Journal of Dairy Science, Madison, v. 91, n. 1, p. 301307, 2008.

HOLDEN, L. Comparison of methods of in vitro dry matter digestibility for ten feeds. Journal of Dairy Science, Madison, v. 82, n. 8, p. 1791-1794, 1999.

JOBIM, C. C.; NUSSIO, L. G.; REIS, R. A.; SCHMIDT, P. Avanços metodológicos na avaliação da qualidade da forragem conservada. Revista Brasileira de Zootecnia, Viçosa, MG, v. 36, n. 10, p. 101-119, 2007.

JOBIM, C. C.; NUSSIO, L. G. Princípios básicos da fermentação na ensilagem. In: REIS, R. A.; BERNARDES, T. F.; SIQUEIRA, G. R. Forragicultura: ciência, tecnologia e gestão de recursos forrageiros. Jaboticabal: Brandel, 2013. cap. 40, p. 649-660.

KAMOTA, A.; MUCHAONYERWA, P.; MNKENI, P. $\mathrm{N}$. Effects of ensiling of Bacillus thuringiensis $(\mathrm{Bt})$ maize (MON810) on degradation of the crystal $1 \mathrm{Ab}$ (Cry1Ab) protein and compositional quality of silage. African Journal of Biotechnology, v. 10, n. 76, p. 17484-17489, 2011.

KUNG, L.; SHAVER, R. Interpretation and use of silage fermentation analysis reports. Focus on Forage, Wisconsin, v. 3, n. 13, p. 1-5, 2001.

LI, P.; BAI, S.; YOU, M.; SHEN, Y. Effects of maturity stage and lactic acid bacteria on the fermentation quality and aerobic stability of Siberian wildrye silage. Food Science \& Nutrition, London, v. 4, n. 5, p. 664-670, 2016.

MCDONALD, P.; HERDERSON, A. R.; HERON, S. J. E. The biochemistry of silage. Marlow: Chalcombe Publication, 1991. 226p.

MEINERZ, G. R. OLIVO, J. C.; VIÉGAS, J.; NÖRNBERG, J. L.; AGNOLIN, C. A.; CHEIBLER, R. B.; HORST, T.; FONTANELI, R.S. Silagem de cereais de inverno submetidos ao manejo de duplo propósito. Revista Brasileira de Zootecnia, Viçosa, MG, v. 40, n. 10, p. 2097-2104, 2011.
PAHLOW, G. ; MUCK, R. E.; DRIEHUIS, F. Microbiology of ensiling. In: BUXTON, D. R.; MUCK, R. E.; HARRISON, J. H. (Ed.). Silage science and technology. Madison: American Society of Agronomy, Crop Science Society of America and Soil Science Society Of America, 2003. p. 31-94.

POERSCHMANN, J.; GATHMANN, A.; AUGUSTIN, J.; LANGER, U.; GÓRECKI, T. Molecular composition of leaves and stems of genetically modified Bt and nearisogenic non-Bt maize-characterization of lignin patterns. Journal of Environmental Quality, Madison, v. 34, n. 5, p. 1508-1518, 2005.

RATKOWSKY, D.; OLLEY, J.; McMEEKIN, T. A.; BALL, A. Relationship between temperature and growth rate of bacterial cultures. Journal of Bacteriology, Washington, v. 149, n. 1, p. 1-5, 1982.

SAXENA, D.; STOTZKY, G. Bt corn has a higher lignin content than non-Bt corn. American Journal of Botany, St. Louis, v. 88, n. 9, p. 1704-1706, 2001.

SNIFFEN, C.; O'CONNOR, J. D.; VAN SOEST, P. J.; FOX, D. G.; RUSSEL, J. B. A net carbohydrate and protein system for evaluating cattle diets: II. Carbohydrate and protein availability. Journal of Animal Science, Champaign, v. 70, n. 11, p. 3562-3577, 1992.

SILVA, D. J.; QUEIROZ, A. C. Análise de alimentos, métodos químicos e biológicos. $3^{a}$. ed. $-4^{a}$ impressão. Universidade Federal de Viçosa. 2002. 235 p.

STATISTICAL ANALYSIS SYSTEM INSTITUTE - SAS. Institute Inc. Statistical Analysis System Introductory Guide for Personal Computers. Release. Cary: Sas Institute Inc., 2002.

TAIZ, L.; ZEIGER, E. Fisiología vegetal/plant physiology. Redwood: The Benjamin/Cummings Publishings Company 2006. 565 p.

VAN SOEST, P. V.; ROBERTSON, J.; LEWIS, B. Methods for dietary fiber, neutral detergent fiber, and nonstarch polysaccharides in relation to animal nutrition. Journal of Dairy Science, Madison, v. 74, n. 10, p. 35833597, 1991.

WILKINSON, J.; DAVIES, D. The aerobic stability of silage: key findings and recent developments. Grass and Forage Science, Nantwich, v. 68, n. 1, p. 1-19, 2013. 